\title{
Effects of chromium picolinate, L-carnitine and thyroxine on the performance, nutrient digestibility and nitrogen balance in pigs weaned at 21 days of age*
}

\author{
W.T. Cho, In K. Han'1, B.J. Chae'2, Y.K. Han ${ }^{3}$, J.K. Ha and J. Odle ${ }^{4}$ \\ Department of Animal Science and Technology, \\ College of Agriculture and Life Sciences, Seoul National University \\ Suweon 441-744, Korea
}

(Received 3 January 2000; accepted 4 October 2000)

\section{ABSTRACT}

A 3-week-growth trial was conducted to investigate the effects of chromium picolinate, L-carnitine, and thyroxine on the growth performance, nutrient digestibility, and $\mathrm{N}$ balance in starter pigs. Eighty starter pigs (Landrace x Yorkshire x Duroc, $21 \pm 2$ days of age, $5.4 \mathrm{~kg}$ of average initial body weight) were employed in a completely randomized block design with four treatments: 1 . Control: without additives, 2. CrP: control diet $+0.05 \%$ of chromium picolinate, 3 . Carnitine: control diet + $0.5 \%$ of Carnifeed $(10 \%$ of carnitine $), 4$. Thyroxine: control diet $+\mathrm{L}$-thyroxine injection $(0.1 \mathrm{mg} / \mathrm{day} /$ head), 5 replications and 4 heads per pen. Although there were no significant differences $(P>0.05)$ in average daily gain (ADG) and average daily feed intake (ADFI), all of the pigs supplemented with $\mathrm{CrP}$, L-carnitine and thyroxine grew better than pigs in the control group. Pigs fed L-carnitine showed the best ADG ( $15 \%$ of improvement compared with control group) through the entire experimental period and feed/gain ratio was improved $(\mathrm{P}<0.05)$. Digestibilities of energy, dry matter, crude protein and crude ash were improved $(\mathrm{P}<0.05)$ by the inclusion of L-carnitine, chromium picolinate or injection of thyroxine. Pigs fed chromium picolinate showed the best nutrient digestibilities. In a $\mathrm{N}$ balance trial, excreted $\mathrm{N}$ was lower $(\mathrm{P}<0.05)$ in pigs of all treated groups than in the control group. The $\mathrm{N}$ in feed also was more efficiently retained in pigs of treated groups. The DNA content of the liver

* This study was funded by KOSEF (Korean Science and Engineering Foundation) in Korea and is a part of Ph.D. Dissertation of W. T. Cho at Seoul National University

Corresponding author

2 Division of Animal Resource, Kangwon National University, Chunchon, Korea

${ }^{3}$ National Livestock Cooperatives Federation, Korea

${ }^{4}$ Department of Animal Science, North Carolina State University, NC 27695, USA 
was higher $(\mathrm{P}<0.05)$ in all treated groups. Only the pigs fed $\mathrm{L}$-carnitine showed a higher $(\mathrm{P}<0.05)$ RNA content. The protein content of the liver tended to be higher $(P>0.05)$ in pigs fed cliromium picolinate or injected L-thyroxine. Total liver DNA. RNA and protein contents were higher $(\mathrm{P}<0.05)$ In pigs fed L-carnitine. It may be concluded that chromium picolinate. L-carnitine and thyroxine may be useful for improving growth rate, nutrient digestibilities, and $\mathrm{N}$ balance in pigs weaned at 21 days of age. although the feasibility of an economic return seems quite weak.

KEY WORDS: chromium picolinate, L-camitine, thyroxine, growth. digestibility, $\mathrm{N}$ balance, starter pig

\section{INTRODUCTION}

Postweaning growth lag has been regarded as a serious problem in the swine industry. Thus, researchers have investigated means to improve post-weaning growth. It has been reported that the $\mathrm{Cr}$ requirement could increase in humans and in animals as a consequence of factors usually described as 'stressors' such as fatigue, trauma, pregnancy and several forms of nutritional, metabolic, physical, environmental and also emotional stress (Burton, 1995). Mooncy and Cromwell (1997) reported that supplementation of organic chromium $(200 \mu \mathrm{g} / \mathrm{kg}$ in the dict) from chromium picolinate resulted in a slightly better weight gain and feed conversion ratio without significant difference. Furthermore, chromium picolinate may improve $\mathrm{N}$ digestibility and $\mathrm{N}$ absorption (Koncrgay ct al., 1997).

Recently, researchers have been interested in the role of dietary L-carnitine in swine nutrition. It is reported that inclusion of dietary L-carnitine could enhance the growth performance of starter pigs (Weeden et al., 1990; Owen et al., 1996; Cho et al., 1999a,b). Furthermore, L-carnitine could improve $N$ digestibility, $\mathrm{N}$ retention rate as well as biological valuc of fecds in pigs (Heo et al., 1999). Numerous studies with starter pigs (Weeden et al., 1990; Newton and Burtlc, 1992; Owen et al., 1996) have shown that L-carnitine might be beneficial when added to diets for nconatal and starter pigs.

Thyroid hormones are necessary for normal growth, development, and a varicty of metabolic functions including muscle protein synthesis and breakdown (Flaim et al., 1978; Brown and Millward, 1983; Hayashi et al., 1984), growth hormone metabolism (Harvey, 1983) and heat production (Bowen et al., 1984). Although it is well established that thyroid hormones are required for normal growth, limited research has been conducted with pigs. Furthermore, no further investigations were found regarding pig production.

Though use of chromium picolinate, L-carnitine and L-thyroxine has reccived intensive interest in starter piglet nutrition, results from studies with chromium picolinate and thyroxine have been inconsistent, and limited rescarch with L-carnitine has been conducted only recently in the field of swine nutrition. Furthermore, 
information is scarce on nutrient digestibility and especially $\mathrm{N}$ balance and DNA, RNA and protein concentration in the liver of starter piglets. Therefore, the objective of the present study was to examine the nutritional values of chromium picolinate, L-carnitine and thyroxine comparing the growth, nutrient digestibilities, $\mathrm{N}$ balance, DNA, RNA and protein concentration in the liver of starter pigs.

\section{MATERIAL AND METHODS}

Eighty starter piglets (Landrace $x$ Yorkshire $x$ Duroc) that averaged $21 \pm 2$ days of age and $5.4 \mathrm{~kg}$ of body weight were weaned and housed in $1 \times 2 \mathrm{~m}^{2}$ pens with concrete slat floor according to a completely randomized block design. Room temperature was maintained at $29 \pm 1{ }^{\circ} \mathrm{C}$. For the first 2 days of the pre-experimental period, pigs were fed a commercial pre-starter diet for adaptation. Pigs were grouped into 5 replications and 4 heads per replicate.

Treatments were: 1 . Control: without additives, 2 . CrP: control diet $+0.05 \%$ of chromium picolinate $(200 \mu \mathrm{g} / \mathrm{kg}$ as chromium $)$, 3. Carnitine: control diet $+0.5 \%$ of Carnifecd ( $500 \mathrm{mg} / \mathrm{kg}$ as L-carnitine), 4. Thyroxine: control diet + L-thyroxine solution injection $(0.1 \mathrm{mg} /$ day/head $)$. Pigs in the Thyroxine group were injected daily with L-thyroxine (Sigma Chemical Company, St. Louis, USA) solution that was diluted in $100 \mu \mathrm{g} / \mathrm{ml} 0.04 \mathrm{~N} \mathrm{NaOH}$.

Experimental diets were formulated to contain $3.41 \mathrm{Mcal} / \mathrm{kg}$ diet of metabolisable energy, $23.01 \%$ of crude protein, $1.65 \%$ of lysine, $0.47 \%$ of methionine, $0.9 \%$ of $\mathrm{Ca}$ and $0.8 \%$ of $\mathrm{P}$ (Table 1). Adequate amounts of vitamins and mincrals were used as suggested by the NRC (1998). Chromic oxide $\left(\mathrm{Cr}_{2} \mathrm{O}_{3}\right)$ was added $(0.2 \%$ in the dict $)$ as an indigestible marker to allow digestibility determinations (McDonald et al., 1995).

Pigs were allowed ad libitum access to water and diets during the 21 -day growth trial, and all diets were given in mash form. Body weights and feed intakes were measured at day 7,14 and day 21 from the beginning of the experiment. Average daily gain (ADG), average daily feed intake (ADFI) and feed/gain (F/G) were calculated on a group basis at each time point.

For the determination of nutrient digestibilities and $\mathrm{N}$ balance, a metabolic trial with 16 pigs ( $11.5 \mathrm{~kg}$ of average initial body weight) was conducted. Pigs with similar body weights were allotted in a completely randomized block design. For the first 10 days of the pre-experimental period, pigs were fed the experimental dict for adaptation to the metabolic crates $\left(45 \times 55 \times 47 \mathrm{~cm}^{2}\right.$ width $\mathrm{x}$ length $\mathrm{x}$ height). Collected (for 3 days) faecal samples were pooled after a 4-day introduction of the experimental diet, and dried in an air-forced drying oven at $60^{\circ} \mathrm{C}$ for $72 \mathrm{~h}$ and ground with $1 \mathrm{~mm}(18 \mathrm{mesh})$ Wilcy mill for further chemical analyses. Individual urinary samples were collected and pooled 3 times a day in a plastic bottle 
(2 liter) containing $50 \mathrm{~mL}$ of $25 \%$ sulphuric acid $\left(\mathrm{H}_{2} \mathrm{SO}_{4}\right)$ to minimize the $\mathrm{N}$ loss by evaporation of ammonia and to maintain the $\mathrm{pH}$ of the urine below 2 . Urine was stored at $-20^{\circ} \mathrm{C}$ and dried faeces at $4^{\circ} \mathrm{C}$ (Canh et al., 1997).

Proximate composition of diets, faeces, and urine were analyzed according to AOAC (1990), and Cr was measured by an atomic absorption spectrophotometer (Shimadzu, AA-6410F, Japan). Gross energy content was measured using an adiabatic bomb calorimeter (Model 1241, Parr Instrument Co.. USA).

TABLE 1

Formula and chemical composition of the experimental diets

\begin{tabular}{|c|c|c|c|c|}
\hline & \multicolumn{4}{|c|}{ Treatment } \\
\hline & Control & $\mathrm{CrP}$ & Camitine & Thyroxine \\
\hline \multicolumn{5}{|l|}{ Ingredients } \\
\hline maize, yellow & 15.80 & 15.92 & 15.20 & 15.80 \\
\hline milk replacer & 23.00 & 23.00 & 22.77 & 23.00 \\
\hline soyabcan meal & 18.02 & 18.03 & 18.22 & 18.02 \\
\hline lactose & 20.20 & 20.00 & 20.00 & 20.20 \\
\hline soya oil & 4.27 & 4.30 & 4.61 & 4.27 \\
\hline fish meal & 5.00 & 5.00 & 5.00 & 5.00 \\
\hline spray dried plasma protein & 5.00 & 5.00 & 5.00 & 5.00 \\
\hline dried porcine soluble & 6.00 & 6.00 & 6.00 & 6.00 \\
\hline monocalciumphosphate & 1.02 & 1.02 & 1.02 & 1.02 \\
\hline limestone & 0.66 & 0.66 & 0.66 & 0.66 \\
\hline vitamin mixture' & 0.20 & 0.20 & 0.20 & 0.20 \\
\hline mineral mixture & 0.30 & 0.30 & 0.30 & 0.30 \\
\hline salt & 0.30 & 0.30 & 0.30 & 0.30 \\
\hline Avilantycin & 0.05 & 0.05 & 0.05 & 0.05 \\
\hline L-lysine $\cdot \mathrm{HCl}$ & 0.09 & 0.09 & 0.09 & 0.09 \\
\hline DL-methionine & 0.09 & 0.08 & 0.08 & 0.09 \\
\hline chromium picolinate & 0.00 & 0.05 & 0.00 & 0.00 \\
\hline L-camitine & 0.00 & 0.00 & 0.50 & 0.00 \\
\hline \multicolumn{5}{|l|}{ Chemical composition ${ }^{3}$} \\
\hline metabolisable energy, Mcal/kg & 3.41 & 3.41 & 3.41 & 3.41 \\
\hline crude protein & $23.0 !$ & 23.01 & 23.01 & 23.01 \\
\hline lysine & 1.65 & 1.65 & 1.65 & 1.65 \\
\hline methionine & 0.47 & 0.47 & 0.47 & 0.47 \\
\hline $\mathrm{Ca}$ & 0.90 & 0.90 & 0.90 & 0.90 \\
\hline $\mathrm{P}$ & 0.80 & 0.80 & 0.80 & 0.80 \\
\hline
\end{tabular}

' contains per kg diet : vit. A, 4,000,000 IU; vit. D, $800,000 \mathrm{IU}$; vit. E., 16,000 IU; vit. K, I,200 mg; vit. $B_{2}, 1,600 \mathrm{mg}$; calcium pantothenate, $4,000 \mathrm{mg} ;$ niacin, $8,000 \mathrm{mg}$; vit. $\mathrm{B}_{12}, 6 \mathrm{mg}$; biotin, $32 \mathrm{mg}$ : ethoxyquin, $6,000 \mathrm{mg}$

? contains per kg diet: $\mathrm{Mn}, 12,000 \mathrm{mg} ; \mathrm{Zn}, 15,000 \mathrm{mg}$; Co, $100 \mathrm{mg} ; \mathrm{Cu}, 500 \mathrm{mg} ; \mathrm{Fc} 4,000 \mathrm{mg}$; BHT, $5,000 \mathrm{mg}$

3 calculated values 
Sixty pigs used in the metabolic trial were anaesthetized for the liver biopsy. Liver samples were collected and frozen in liquid nitrogen and stored at $-70^{\circ} \mathrm{C}$ until they were analyzed for DNA and RNA contents (Sambrook et al., 1987; Buskirk et al., 1996), and protein contents using the Bradford assay (Bollag and Edclstein, 1991).

Statistical analysis of data was carricd out by comparing means using the LSD (least significant difference) test, and the GLM procedure of the SAS (1990) package program.

\section{RESULTS AND DISCUSSION}

\section{Growth performance}

There were no significant differences in ADG and ADFI (Table 2); however, all treated pigs tended to grow better $(\mathrm{P}>0.05)$ than pigs in the control group. Pigs fed L-carnitine showed the best ADG (15\% of improvement compared with control group) through the entire experimental period and the $F / G$ was improved $(\mathrm{P}<0.05)$. For the first 7 days of the experimental period, supplementation of L-carnitine did not improve $(\mathrm{P}>0.05)$ the ADG. Pigs in treated groups showed improved feed conversion ratio ( $\mathrm{P}>0.05$ ) when compared with that of pigs in the control group. Similar trends were observed in the 2 nd and 3 rd week of the trial. The ADG of pigs fed L-carnitine during days 7 to 14 day and 14 to 21 were improved by 20 and $15 \%$, respectively. While pigs fed chromium picolinate did not show improvements in ADG during days 7 to 14, pigs injected L-thyroxine showed similar improvement $(17 \%)$ to that of pigs fed L-carnitine. For the last week of the trial ( 14 to 21 day), pigs fed chromium picolinate and those injected with L-thyroxine showed improvements in ADG by 11 and 13\%, respectively.

In the limited literature on chromium in starter pigs, it is generally reported that $200 \mu \mathrm{g} / \mathrm{kg}$ of $\mathrm{Cr}$ does not impair the growth rate and feed intake or efficiency of feed utilisation of pigs (Page et al., 1993). Lindmann et al. (1995) did not find any improvements in growth rate with the supplementation of chromium picolinate, while the $\mathrm{F} / \mathrm{G}$ ratio was improved, which corresponds with the results of the present study. In contrast, Mooney and Cromwell (1995) found an improvement in growth rate but the $\mathrm{F} / \mathrm{G}$ ratio was not influenced by the supplementation of dietary chromium picolinatc. Lein et al. (1996) reported an increase in growth and fecd intake attributed to the supplementation of dietary chromium picolinate. Our previous study (Cho et al., 1999b) also indicated that inclusion of $200 \mu \mathrm{g} / \mathrm{kg} \mathrm{Cr}$ as chromium picolinate improved $(\mathrm{P}<0.05)$ the growth performance of starter piglets. Mooney and Cromwell (1997) reported that though there was no significant difference, supplementation of organic $\mathrm{Cr}(200 \mu \mathrm{g} / \mathrm{kg} \mathrm{Cr})$ from chromium picolinate 
TABLE 2

Effect of chromium picolinate, carnitine and thyroxine on the performance of pigs weaned at 2 I days of agc ${ }^{1}$

\begin{tabular}{|c|c|c|c|c|c|}
\hline & Control & $\mathrm{CrP}$ & Carnitine & Thyroxine & $\mathrm{SE}^{2}$ \\
\hline \multicolumn{6}{|l|}{$0-7$ day } \\
\hline $\mathrm{ADG}$ & 226.2 & 230.4 & 240.0 & 225.8 & 10.10 \\
\hline$\Lambda \mathrm{DFI}$ & 269.2 & 253.6 & 261.6 & 246.6 & 10.70 \\
\hline $\mathrm{F} / \mathrm{G}$ & $1.19^{\prime \prime}$ & $1.10^{\mathrm{b}}$ & $1.09^{\mathrm{h}}$ & $1.09^{\mathrm{h}}$ & 0.011 \\
\hline \multicolumn{6}{|l|}{ 7. 14 day } \\
\hline $\mathrm{ADG}$ & 295.8 & 293.6 & 354.6 & 346.6 & 13.26 \\
\hline ADFI & 421.8 & 419.0 & 471.8 & 479.0 & 17.46 \\
\hline $\mathrm{F} / \mathrm{G}$ & $1.42^{\prime \prime}$ & $1.43^{a}$ & $1.33^{\mathrm{h}}$ & $1.38^{\mathrm{bb}}$ & 0.012 \\
\hline \multicolumn{6}{|c|}{$14-2 !$ day } \\
\hline ADG & 323.0 & 359.0 & 371.4 & 364.0 & 11.41 \\
\hline ADFI & 507.0 & 542.4 & 547.8 & 562.6 & 18.15 \\
\hline $\mathrm{F} / \mathrm{G}$ & $1.57^{\circ}$ & $1.50^{\mathrm{ilh}}$ & $1.47^{\mathrm{h}}$ & $1.55^{\circ}$ & 0.013 \\
\hline \multicolumn{6}{|l|}{$0-21$ day } \\
\hline ADG & 281.6 & 294.4 & 322.2 & 317.8 & 9.97 \\
\hline ADFI & 399.2 & 405.0 & 427.0 & 429.6 & 13.41 \\
\hline $\mathrm{F} / \mathrm{G}$ & $1.42^{\circ}$ & $1.38^{\mathrm{ah}}$ & $1.33^{\circ}$ & $1.35^{h \mathrm{~h}}$ & 0.010 \\
\hline
\end{tabular}

1 average initial body weight of pigs was $5.4 \mathrm{~kg}$ and the final body weight was $11.7 \mathrm{~kg}$

2 standard error of the mean, $n=20$ pigs $/$ treat

a.b.c $\mathrm{P}<0.05$

resulted in slightly better weight gain and feed conversion ratio. The present study showed a slightly better growth rate and improved $(\mathrm{P}<0.05) \mathrm{F} / \mathrm{G}$ ratio through the entire experimental period. These results suggest an inconsistent effect of $\mathrm{Cr}$ (as chromium picolinate) on the growth performance of pigs.

It is reported that weaning pigs might be deficient in ascorbic acid, which is crucial for endogenous carnitine synthesis (Mahan et al., 1994). In general, carnitine is low in feed ingredients of plant origin and high in animal sources (Owen et al., 1997). Grains and oilseed meals are low in carnitine whereas feed ingredients from animal sources (such as milk products) do contain carnitine. However, plasma protein that is universally used in weaner diets has a low carnitine content (Lonza, 1996; Neumann, 1996).

Regardless of the different inclusion level of dictary L-camitine, our previous studies (Cho et al., 1999a,b) reported that use of L-carnitine was beneficial for the carly growth of starter piglets. Similarly, the growth rate tended to be improved $(\mathrm{P}>0.05)$ through the entire experimental period with the inclusion of dietary L-carnitine. While Ewan (1987) and Hoffman et al. (1993) reported no improve- 
ment in growth rate with the supplementation of dietary carnitine, Owen et al. $(1994,1996)$ reported that dictary L-carnitine addition $(1,000 \mathrm{mg} / \mathrm{kg})$ improved growth performance when fed during the nursery phase. Similarly, Fremaut (1993) and Galvez et al. (1996) also found an improved $\mathrm{F} / \mathrm{G}$ ratio in their experiments with starter piglets. Li et al. (1999) reported that carnitine had no effect in the first 2 weeks after weaning ( 35 days of age); however, there was a highly significant effect of increasing growth during the period of 14 to 28 days after weaning. Some studies (Weeden et al., 1990, 1991; Galvez et al., 1996; Owen et al., 1996) supported that L-camitine seemed to improve the growth of starter piglets after three to four weeks post weaning; however, Galvez et al. (1996) explained that this might be due to the L-carnitine from sow milk during lactation and biosynthesis by the piglets after weaning being enough to utilize solid post-wcaning diets.

Scarce information is available on the effect of thyroxine in pigs. KaciubaUscilko et al. (1970) reported a reduced growth rate following three successive injections of thyroxine. They observed that thyroxine-treated animals were lower $(\mathrm{P}<0.05)$ in weight gain than the saline controls at 2-4 weeks after injection (300 $\mu \mathrm{g} \mathrm{kg} / \mathrm{kg}$ body weight) in new-born piglets. Suthama et al. (1989) reported that dietary inclusion of thyroxine $(1.2 \mathrm{mg} / \mathrm{kg})$ in broiler's diet did not impair the growth rate; however, feed consumption was lowered by $6 \%$ and feed efficiency was improved by $11 \%$. They (Suthama et al., 1991) also reported that if broilers were fed adequate dietary protein, thyroxine did not impair the growth of broiler chickens. Similarly, Kim ct al. (1993) observed no difference in growth rate of broiler chickens fed $1.5 \mathrm{mg} / \mathrm{kg}$ of dietary thyroxine, but when the level of thyroxine was increased to $3.0 \mathrm{mg} / \mathrm{kg}$, the growth rate was lowered $(\mathrm{P}<0.05)$. Marple et al. (1981) noted the importance of thyroxine for growth of pigs. They investigated the relationship between thyroxine secretion and growth rate and showed that higher concentrations of thyroxine at 14 and 18 wecks of age coincided with the period in which the most rapid relative growth was observed; that is, body weight had approximately doubled from 10 to 14 and 14 to 18 weeks of age. The changes in relative growth rate and thyroxine concentrations support the classical obscrvations that thyroid hormones are necessary for growth. Galton (1975) observed increased growth rate in rats receiving thyroxinc in doses ranging from 1.5 to $30 \mu \mathrm{g} /$ day (approximately 1 to $20 \mu \mathrm{g} / 100 \mathrm{~g}$ body weight). Rats given the higher doses continued to gain weight, although at a slower rate than did those given the low doses of thyroxine.

\section{Nutrient digestibility}

Digestibilities of energy, dry matter, crude protein and crude ash were improved $(\mathrm{P}<0.05)$ by the inclusion of L-carnitine, chromium picolinate or injection of thyroxine. No difference was found in crude fat digestibility between pigs in Control 
and Thyroxine groups. Pigs fed chromium picolinate showed the best nutrient digestibilities. Though there were no significant differences, elevated growth rates of pigs and feed conversions scemed to be explained by the higher nutrient digestibilities (Table 3 ).

TABLE 3

Effect of chromium picolinatc, carnitine and thyroxine on the nutrient digestibility of pigs weaned at 21 days of age

\begin{tabular}{lccccc}
\hline & Control & CrP & Carnitine & Thyroxine & SE' $^{\prime}$ \\
\hline Energy & $86.52^{\mathrm{d}}$ & $89.24^{\mathrm{a}}$ & $88.58^{\mathrm{b}}$ & $87.67^{\mathrm{c}}$ & 0.27 \\
Dry matter & $86.86^{\mathrm{a}}$ & $89.83^{\mathrm{a}}$ & $89.29^{\mathrm{b}}$ & $88.49^{\mathrm{c}}$ & 0.29 \\
Crude protein & $80.41^{\mathrm{c}}$ & $85.20^{\mathrm{a}}$ & $83.38^{\mathrm{h}}$ & $83.54^{\mathrm{h}}$ & 0.45 \\
Crude fat & $86.41^{\mathrm{b}}$ & $88.88^{\mathrm{a}}$ & $87.69^{\mathrm{b}}$ & $86.91^{\mathrm{b}}$ & 0.26 \\
Crude ash & $54.62^{\mathrm{a}}$ & $68.49^{\mathrm{a}}$ & $68.86^{\mathrm{a}}$ & $64.06^{\mathrm{h}}$ & 1.49 \\
\hline
\end{tabular}

${ }^{1}$ standard error of the mean, $n=4$ pigs/treat a.b.c.d $\mathrm{P}<0.05$

Our previous study (Cho et al., 1999b) showed that supplementation of chromium picolinate and L-carnitine improved $(\mathrm{P}<0.05)$ nutrient digestibility. Konergay et al. (1997) reported that inclusion of chromium picolinate improved the digestibility of dry matter by $1.3 \%(87.7 \%)$ compared with controls. Scarce information is available on the effect of chromium picolinate, L-carnitine and thyroxine on nutrient digestibilities in pigs. Hoffman et al. (1993) reported no improvement in energy utilisation in neonatal and young pigs fed L-carnitine. However, previous studics (Broquist, 1982; Borum, 1983; Bremer, 1983; Rebouche and Paulson, 1986). showed that added L-carnitinc improved fat utilisation, especially fatty acids in $\beta$-oxidation in mammals. Also Cho et al. (1999a) reported that L-carnitine improved the crude fat and gross energy digestibility in starter piglets.

\section{Nitrogen balance}

As shown in Table 4, excreted $\mathrm{N}$ via faeces and urine were lower $(\mathrm{P}<0.05)$ in all treated pigs than in controls. Feed $\mathrm{N}$ was also more efficiently retained in pigs of the treated groups. These higher $\mathrm{N}$ efficiencics also could explain the higher crude protein digestibility and growth rate effects.

Gencrally, chromium picolinate has been regarded as a carcass modificr. Page et al. (1993), Lindmann and Purser (1997) and Porter (1997) reported that organic chromium stimulated protein growth, resulting in higher lean percentage. Furthermore, recently Konergay et al. (1997) reported that $\mathrm{N}$ absorption of pigs fed chromium picolinate was improved $(\mathrm{P}<0.05)$. Similarly L-carnitine was reported to improve daily protein accretion (Heo et al., 1999). They noted two possible ways. 
TABLE 4

Effect of chromium picolinate, carnitine and thyroxine on the $\mathrm{N}$ balance of pigs weaned at 21 days of age

\begin{tabular}{lccccc}
\hline & Control & CrP & Carnitine & Thyroxine & SE' $^{\prime}$ \\
\hline N intake, g & 22.47 & 22.91 & 22.36 & 22.59 & 0.41 \\
Faecal N, g & $4.40^{\mathrm{a}}$ & $3.39^{\mathrm{c}}$ & $3.72^{\mathrm{b}}$ & $3.72^{\mathrm{b}}$ & 0.12 \\
Urinary N, g & $3.00^{\mathrm{a}}$ & $2.40^{\mathrm{b}}$ & $2.40^{\mathrm{b}}$ & $2.43^{\mathrm{b}}$ & 0.12 \\
Retained N/N intake & $67.12^{\mathrm{c}}$ & $74.88^{\mathrm{a}}$ & $72.66^{\mathrm{b}}$ & $72.76^{\mathrm{b}}$ & 0.80 \\
Biological value* & $83.47^{\mathrm{b}}$ & $87.90^{\mathrm{a}}$ & $87.14^{\mathrm{a}}$ & $87.10^{\mathrm{a}}$ & 0.59 \\
N digestibility & $80.41^{\mathrm{c}}$ & $85.20^{\mathrm{a}}$ & $83.38^{\mathrm{b}}$ & $83.54^{\mathrm{b}}$ & 0.45 \\
\hline
\end{tabular}

* retained N/absorbed $\mathrm{N}$

' standard error of the mean, $n=4$ pigs/treat

w.h.s. $\mathrm{P}<0.05$

One is that L-carnitine increased $\beta$-oxidation of fatty acids which could supply more encrgy for protein synthesis. Or lysine degradation was reduced by the increased energy from fat, and more dietary amino acids could be directed toward protein synthesis. Kim et al. (1993) reported that an increased level of dictary thyroxine $(0$ to $3.0 \mathrm{mg} / \mathrm{kg})$ resulted in higher protein accretion, while crude fat content was decreased in broiler chickens. Wilson et al. (1983) observed a decrease in abdominal fat content when broilers fed dietary thyroactive iodinated cascin, and it could be assumed that the elevated level of thyroxine induced by the iodinated casein in the diet increased muscle mass and decreased body fat content.

\section{DNA, RNA and protein concentrations in liver}

Hepatic DNA, RNA and protein concentrations were also investigated (Table $5)$. The DNA contents were higher $(\mathrm{P}<0.05)$ in all treated groups. Only the pigs fed L-carnitine showed higher $(\mathrm{P}<0.05)$ RNA content. The protein contents seemed higher in pigs fed chromium picolinate or injected L-thyroxine. Liver DNA, RNA and protein concentrations were all higher $(\mathrm{P}<0.05)$ in pigs fed L-carnitine compared with controls. According to the report from Wilson et al. (1990), total liver DNA, RNA and protein content implies more cells and greater liver protein synthetic capacity in the L-carnitine group in the present study. Total DNA levels could be equated to the number of nuclei and cell number (Encsco and Leblond, 1962). Winick and Noble (1965) and Scornim (1982) reported that changes in total protein (and to some extent total RNA) may reflect changes in both cell number and cell size and the protein:DNA ratio generally reflects changes in cell size. According to the results previously cited, dietary L-carnitinc could increase the number of cells as well as their size. These could support the higher growth rate, nutrient digestibility and the $\mathrm{N}$ absorption of the present study. 
TABLE 5

Effect of chromium picolinate, carnitine and thyroxinc on the DNA. RNA and protein concentrations in the liver of pigs weaned at 21 days of age

\begin{tabular}{lccccc}
\hline & Control & CrP & Carnitine & Thyroxinc & SE' $^{\prime}$ \\
\hline DN $A, \mathrm{mg} / \mathrm{g}$ liver & $1.013^{\mathrm{b}}$ & $1.741^{\mathrm{b}}$ & $2.271^{\mathrm{a}}$ & $1.828^{\mathrm{b}}$ & 0.1437 \\
RNA, mg/g liver & $1.528^{\mathrm{b}}$ & $1.411^{\mathrm{b}}$ & $5.110^{\mathrm{a}}$ & $1.506^{\mathrm{b}}$ & 0.4824 \\
Protein, mg/g liver & $0.184^{\mathrm{b}}$ & $0.203^{\mathrm{b}}$ & $0.273^{\mathrm{a}}$ & $0.248^{\mathrm{b}}$ & 0.0132 \\
RNA/DNA, mg/mg & $1.507^{\mathrm{b}}$ & $0.817^{\mathrm{b}}$ & $2.277^{\mathrm{a}}$ & $0.823^{\mathrm{b}}$ & 0.0002 \\
Protein/DNA, mg/mg & $0.181^{\mathrm{a}}$ & $0.117^{\mathrm{b}}$ & $0.121^{\mathrm{b}}$ & $0.136^{\mathrm{b}}$ & 0.0085 \\
Protein/RNA. mg/mg & $0.120^{\mathrm{b}}$ & $0.143^{\mathrm{b}}$ & $0.054^{\mathrm{d}}$ & $0.165^{\mathrm{a}}$ & 0.0126 \\
\hline
\end{tabular}

I standard error of the mean, $\mathrm{n}=4$ plgs/treat

4.h. . id $\mathrm{P}<0.05$

\section{CONCLUSIONS}

Conclusively, $200 \mu \mathrm{g} / \mathrm{kg}$ of chromium picolinate, $500 \mathrm{mg} / \mathrm{kg}$ of L-carnitine and $0.1 \mathrm{mg} /$ day/head of thyroxine injection may be useful in terms of growth and nutrient utilisation in pigs weaned at 21 days of age. Furthermore, the nitrogen balance sustains the growth promoting effect of L-carnitine, chromium picolinate and the L-thyroxine in starter pigs. However, further studies are needed to obtain biochemical and economic values as well.

\section{REFERENCES}

AOAC, 1990. Official Method of Analysis. 15th Edition. Association of Official Analytical Chemists. Arlington, VA

Bae K.K.. 1999. Eeffects of netabolic active substances on the growth and carcass characteristics in finishing pigs. Ph.D. Dissertation. Seoul National University. Scoul (Korea)

Bollag D.M., Edelstein S.J.. 1991. Protein Methods. Wiley-Liss. A John Wiley and Sons. Inc., USA, pp. $50-55$

Borum P.R., 1983. Carnitine. Ann. Rev. Nutr, 3, 323-359

Bremer J., 1983. Carnitine-metabolism and functions. Physiol. Rev. 63, 1420-1480

Broquist H.P., 1982. Carnitine biosynthesis and functions. Introductory remarks. Fed. Proc. 41, 2840

Brown J.G., Millward D.J., 1983. Dose response of protein tunrover in rat skeletal muscle of triiodothyronine treatment. Biochem. Biophys. Acta. 757, 182-190

Bowen S.I., Washbum K.W., Huston T.M., 1984. Involvement of the thyroid gland in the response of young chickens to heat stress. Poultry Sci. 63, 66-69

Burton J.L., 1995. Supplemental chromium; its benefits to the bovine immune system. Anim. Feed Sci. Tech. 53, 117-133

Buskirk D.D., Faulkner D.B., Hurley W.L., Kcsler D.J., Ireland F.A., Nash T.G., Castree J.C., Vicini J. L., 1996. Growth reproductive performance, mammary development and milk production of 
beef heifers as influenced by prepubertal dietary energy and administration of bovine somatotropin. J. Anim. Sci. 74, 2649-2662

Canh T.T., Verstegen M.W.A., Aarnink A.J.A., Schrama J.W., 1997. Influence of dietary factors on nitrogen partitioning composition of urine and feces of fattening pigs. J. Anim. Sci. 75, 700-706

Cho W.T., Kim J.H., Han In K., Han Y.K., Heo K., Odle J., 1999a. Effects of L-carnitine with different lysine levels on growth and nutrient digestibility in pigs weaned at 21 days of age. Asian-Austr. J. Anim. Sci. 12, 799-805

Cho W.T., Kim J.H., Kang W.B., Han In K., Han Y.K., 1999b. Effects of L-carnitine, chromium picolinate with different fat sources on growth and nutrient digestibility in pigs weaned at 21 days of age. Korean J. Anim. Sci. 41, 445-456

Enesco M., LeBlond C.P., 1962. Increase in cell number as a factor in the growth of the organs of the young male rat. J. Embryol. Exp. Morphol. 10, 530-562

Ewan R.C., 1987. Effect of L-carnitine and weanling pigs performance. Iowa State University Swine Research Report R481. College of Agriculture, Ames, Iowa (USA), p. 10

Flaim K.E., Li J.B., Jefferson L.S., 1978. Effects of thyroxine on protein turnover in rat skeletal muscle. Amer. J. Physiol. 235, E231

Fremaut D., 1993. L-carnitine in Modern Swine Nutrition. Lonza Ltd., Basle

Friedman L., Gaines D.W., Newell R.F., Smith M.C., Braunberg R.C., Flynn T.J., O’Donnell M.W., Jr., 1995. Growth patterns in selected organs of the miniature swine as determined by gross macromolecular composition. J. Anim. Sci. 73, 1340-1350

Harvey S., 1983. Thyroid hormones inhibit growth hormone secretion in domestic fowl (Gallus domesticus). J. Endocrinol. 96, 329-334

Hayashi K., Akiba Y., Tomita Y., Matsumoto T., 1984. The concerted effects of thyroid function and dietary protein on growth and protein metabolism in mice at different growth stages. J. Nutr. Sci. Vitaminol. 30, 235-244

Heo K.N., Odle J., Han In K., Cho W.T., Seo S.W., van Heugten E., Pilkington D.H., 2000. Dietary L-carnitine improves nitrogen utilization in growing pigs fed low energy, fat-containing diets. J. Nutr. 130, 1809-1814

Hoffman L.A., Ivers D.J., Ellersieck M.R., Veum T.L., 1993. The effect of L-carnitine and soybean oil on performance and nitrogen and energy utilization by neonatal and young pigs. J. Anim. Sci. 71, 132-138

Galton V.A., 1975. Thyroxine metabolism in the rat: effect of varying doses of exogenous thyroxine. Acta Endocrinol. 75, 714-722

Galvez J.F., Baumgartner M., Daza A., Butierrez-Barquin M.G., 1996. L-carnitine boosts piglet growth. Feed Mix. 4, 26-29

Kim J.W., Lee C.H., Han I.K., 1993. Effects of dietary thyroxine on growth performance and carcass quality of broilers fed different levels of dietary protein. Asian-Austr. J. Anim. Sci. 6, 527-539

Kaciuba-Usciłko H., Legge K.F., Mount L.E., 1970. The development of the metabolic response to thyroxine in the new-born pig. J. Physiol. 206, 229-241

Konergay E.T., Wang Z., Wood C.M., Lindmann M.D., 1997. Supplemental chromium picolinate influences nitrogen balance, dry matter digestibility, and carcass traits in growing-finishing pigs. J. Anim. Sci. 75, 1319-1323

Li D.F., Qiao Q., Johnson E.W., Jiang J., Wang F., Blum R., Allee G., 1999. Effect of L-carnitine and source of dietary fat on growth performance and serum biochemical parameters of piglets weaned at 35 days of age. Asian-Austr. J. Anim. Sci. 12, 1263-1272

Lindmann M.D., Wood C.M., Harper A.F., Konergay E.T., Anderson R.A., 1995. Dietary chromium picolinate additions improve gain:feed and carcass characteristics in growing-finishing pigs and increase litter size in reproducing sows. J. Anim. Sci. 73, 457-465 
Lonza, 1996. L-carnitine in Animal Nutrition. Lonza Ltd., Basle

Mahan D.C., Lepine A., Dabrowski K., 1994. Efficacy of magnesium-L-ascorbyl-2-phosphate as a vitamin $\mathrm{C}$ source for weanling and growing-finishing swine. J. Anim. Sci. 72, 2354-2361

Marple D.N., Nachreiner R.F., Pritchett J.F., Kuhlers D.L., 1981. The relationship of thyroxine secretion rate to growth of swine. J. Anim. Sci. 52, 500-504

McDonald P., Edwards R.A., Greenhalgh J.F.D., Morgan C.A., 1995. Animal Nutrition. 5th Edition. Longman Science and Technical, NY (USA), pp. 221-237

Min J.K.. Kim W.Y., Chae B.J., Chung I.B., Shin I.S., Choi Y.J., Han In K., 1997. Effects of chromium picolinate $(\mathrm{CrP})$ on growth performance, carcass characteristics and serum traits in growing-finishing pigs. Asian-Austr. J. Anim. Sci. 10, 8-14

Mooney K.W., Cromwell G.W., 1997. Efficacy of chromium picolinate and chromium chloride as potential carcass modifiers in swine. J. Anim. Sci. 75, 2661-2671

Mooney K.W., Cromwell G.W., 1999. Efficacy of chromium picolinate on performance and tissue accretion in pigs with different lean gain potential. J. Anim. Sci. 77. 1188-1198

Neumann G.. 1996. Effect of L-carnitine on athletic performance. 1n: H Seim, H. Loster (Editors). Carnitine-Pathochemical Basics and Clinical $\Lambda$ pplications. Ponte Press. Bouchum. pp. 61-72

Newton G.L.. Burtle G.J., 1992. Carnitine in food animal production. In:A. L. Carter (Editor). Current Concepts in Carnitine Research. CRC Press. Boca Raton. FL (USA), p. 59

NRC, 1998. Nutrient Requirement of Pigs. 10th Edition. National Research Council. Academy Press. Washington, DC

Owen K.Q.. Nelseen J.L., Goodband R.D., Tokach M.D. Blum S.A., Dritz S.S.. 1994. The effect of dietary L-carnitine on growth performance and tissue accretion rates in the early-weaned pig. Kansas Swine Day, pp. 122-124

Owen K.Q., Kim I.H., Kin C.S., 1997. The sole of L-carnitine in swine nutrition and metabolism. Korean J. Anim. Nutr. Feed. 21, 41-58

Owen K.Q., Nelssen J.L., Goodband R.D., Seeden T.L., Blum S.A., 1996. Effect of L-carnitine and soybean oil on growth performance and body composition of early-weaned pigs. J. Anim. Sci. $74,1612-1619$

Page T.G., Southem I..L., Ward T.L., Thompson D.L., Jr., 1993. Effect of chromium picolinate on growth and serum and carcass traits of growing-finishing pigs. J. Anim. Sci. 71, 656-662

Pond W.G., Mauer R.R.. Klindt J.. 1991. Fetal organ response to maternal protein deprivation during pregnancy in swine. J. Nutr. 121, 504-509

Rebouche C.J., Paulson D., 1986. Carnitine metabolism and functions in humans. Ann. Rev. Nutr. 6 . $4]-66$

Sambrook J., Fritsch E.F., Maniatis T., 1989. Molecular Cloning - A Laboratory Manual. 2nd Edition. Cole Spring Harbor Laboratory Press (USA)

SAS, 1990. User's Guide: Statistics. SAS Inst. Inc., Cary. NC

Scornik O.A.. 1982. Protein synthesis and degradation during growth. In: C.T. Jones (Editor). Biochemical Development of the Fetus and Neonate. Chapter 26. Elsevier Biomedica! Press. NY (USA)

Suthama N., Hayashi K., Toyomizu M., Tomita Y., 1989. Effect of dietary thyroxine on growth and muscle protein metabolism in broiler chickens. Poultry Sci. 68, 1396-1401

Suthama N., Hayashi K., Toyomizu M., Tomita Y., 1991. Interaction of exogenous thyroxine and dietary protein levels on growth and muscle protein metabolism in broiler chickens. Jpn. Poultry Sci. $28,1-10$

Weeden T.L., Nelssen J.L., Hanssen J.A., Fitzner G.E., Goodband R.D., 1991. The effect of L-carnitine on starter pig performance and carcass composition J. Anim. Sci. 69, Suppl. 1, 105 ( $\mathrm{\text {bstr}}$ ) 
Wilson H.R., Boonc M.A., Arafa A.S., Janky D.M., 1983. Abdominal fat pad reduction in broilers with thyroactive iodinated casein. Poultry Sci. 62,811-818

Winick M., Noble A. 1965. Quantitative changes in DNA. RNA, and protein during prenatal and postnatal growth in the rat. Develop. Biol. 12, 451-466

\section{STRESZCZENIE}

Wpływ pikolinianu chromu, L-karnityny i tyroksyny na rozwój, strawność składników pokarmowych i bilans azotu u prosiąt odsadzonych w 21 dniu życia

Trzytygodniowe doświadczenie wzrostowe przeprowadzono na 80 prosiętach (Landrace x Yorkshire $x$ Duroc), $21 \pm 2$ dniowych o początkowej m.c. $5.4 \mathrm{~kg}$, stosując układ kompletnych bloków losowych: 1. grupa kontrolna - bez dodatków; 2 . CrP: dieta kontrolna $+0.05 \%$ pikolinianu chromu; 3. karnityna: dieta kontrolna $+0,5 \%$ "Carnifeed" ( $10 \%$ karnityny): 4. tyroksyna: dieta kontrolna + injekcja L-tyroksyny $(0,1 \mathrm{mg} / \mathrm{dzien} / \mathrm{sztukę})$; pięć powtórzeń po 4 prosiçta w grupie. Choć nie było istotnych różnic $(\mathrm{P}>0,05) \mathrm{w}$ dziennym pobraniu paszy i przyrostach dziennych (ADG), ADG prosiąt wszystkich grup doświadczalnych były lepsze niż grupy kontrolnej; przez cały okres doświadczalny ADG prosiąt otrzymujacych dodatek L-kamityny były o 15\% lepsze niż kontrolnych, podobnie jak i wykorzystanie paszy $(\mathrm{P}<0,05)$. Przy zastosowaniu wszystkich dodatków poprawiła się $(\mathrm{P}<0,05)$ strawność energii, s.m., białka ogólnego i popiołu, przy czym najlepsze wyniki uzyskano u prosiąt orrzymującycl pikolinian chromu. Podobnie bilans $\mathrm{N}$ był lepszy $(\mathrm{P}<0,05)$ u prosiąt $\mathrm{z}$ grup doświadczalnych, jak i zawartość DNA w wątrobie była większa $(\mathrm{P}<0,05)$ niż u prosiąt kontrolnych. Zawartość RNA była większa tylko w wątrobie prosiąt otrzymujących L-karnitynę $(\mathrm{P}<0.05)$, a zawartość białka była nieco większa $(\mathrm{P}>0,05)$ u prosiąt otrzymujących pikolinian chromu lub tyroksynę.

Stwierdzono. ze zastosowane dodatki mogą być przydatne jako związki poprawiające przyrosty, strawność składników pokarmowych i bilans $\mathrm{N}$ u prosiąt odsadzonych w 21 dniu życia, lecz. pod znakiem zapytania stoi ckonomika icls stosowania. 